\title{
From opacity to transparency? Evaluating access to information in Brazil five years later
}

\section{Gregory Michener ${ }^{1}$ \\ Evelyn Contreras ${ }^{1}$ \\ Irene Niskier ${ }^{1}$}

1 Fundação Getulio Vargas / Escola Brasileira de Administração Pública e de Empresas, Rio de Janeiro / RJ — Brazil

How well is Brazil's access to information (ATI) law working five years after passage? And what can be done to improve it? Drawing on official data as well as nine evaluations of compliance with ATI obligations, interviews with policymakers, and archival research, this paper provides descriptive and inferential statistics on compliance with ATI requests and indicators of implementation. Results show that less than one in every two requests in Brazil obtains a response from agencies, and more than $50 \%$ of requests exceed the time limits established in the law. Evidence of weak commitments to ATI are also illustrated by the paucity of several key indicators of compliance, including statistics on requests, declared commitments to ATI, ATI-specific platforms for making requests, and designated oversight institutions. Brazil urgently needs to invest in greater information management, empowering oversight institutions to implement and adjudicate ATI obligations.

Keywords: Brazil; freedom of information; transparency.

\section{Da opacidade à transparência? Avaliando a Lei de Acesso à Informação no Brasil cinco anos depois}

Após cinco anos em vigor, quão bem a lei brasileira de acesso à informação (LAI) está funcionando? E o que pode ser feito para melhorar? A partir da análise de dados oficiais, de nove avaliações de cumprimento das obrigações de transparência, de entrevistas com políticos e gestores públicos, e de pesquisa de arquivo, este artigo oferece estatísticas descritivas e inferenciais sobre cumprimento de pedidos de acesso à informação e indicadores de implementação. Os resultados demonstram que menos de uma em cada duas solicitações de Acesso à Informação (AI) no Brasil obtém uma resposta dos governos e mais de 50\% dos pedidos excedem os prazos estabelecidos pela lei. A implementação inconsistente também é ilustrada pela escassez de indicadores de cumprimento, tais como estatísticas governamentais sobre pedidos, compromissos públicos com o AI, plataformas específicas para envio de pedidos de AI e órgãos de controle designados. O Brasil precisa investir urgentemente em maior gerenciamento da informação, capacitando as instituições de controle para implementar e adjudicar as obrigações de transparência.

Palavras-chave: Brasil; acesso à informação; transparência.

\section{¿De la opacidad a la transparencia? Evaluando el acceso a la información en Brasil cinco años después}

¿Qué tan bien funciona la Ley de Acceso a la Información (LAI) brasileña a los cinco años de su entrada en vigor?, y ¿qué se puede hacer para mejorarla? Este artículo ofrece estadística descriptiva e inferencial del cumplimiento con los requerimientos de acceso a la información e indicadores de implementación, en base a información oficial, nueve evaluaciones de cumplimiento, entrevistas con políticos y formuladores de políticas, y revisión documentaria. Los resultados muestran que menos de uno de cada dos pedidos de acceso a la información en Brasil obtiene respuesta de los gobiernos, y en más del 50\% de los casos se excede el plazo máximo de respuesta establecido por ley. Un débil compromiso con el acceso a la información se evidencia también por la falta de varios indicadores claves de cumplimiento, como estadísticas sobre los pedidos, declaraciones de compromiso con el acceso a la información, plataformas específicas para realizar pedidos, y designación de instituciones supervisoras. Brasil necesita invertir con urgencia en una mejor gestión de la información, empoderando a instituciones supervisoras para implementar y juzgar respecto a obligaciones de acceso a la información.

Palabras clave: Brasil; acceso a la información; transparencia. 
Five years ago, Brazil inaugurated a new civic and administrative paradigm. By adopting an access to public information (ATI) law (12.527/2011), the state was transformed from a monopolistic agent of public information to serving citizens as a custodian of 'public information.'

This is an onerous transformation. Information is power, and ATI laws have been called 'revolutionary' and 'subversive' in providing a broad foundational right for accessing government information (Darch and Underwood, 2010:9). But in threatening to tear down the 'paper wall' between citizens and the state, ATI laws have become the object of remarkable public sector resistance (Hood, 2010; Michener, 2015b; Roberts, 2006).

What of this resistance in Brazil, a country that has long struggled with authoritarian legacies? Five years after the passage of Brazil's Lei de Acesso à Informação Pública, this paper assesses the movement from opacity to transparency. It does so by analyzing available government data and an exhaustive compilation of ATI evaluations from across Brazil, placing special emphasis on evaluations carried out by the FGV's Public Transparency Program since 2014.

The absence of broad analyses published on the operation of law 12.527 - especially in terms of passive transparency - represents a significant gap in our understanding of public administration in Brazil. Most extant works analyze active (website-based) transparency, and do so in one or a limited number of jurisdictions (Bairral, Silva and Alves, 2015; Bernardes, Santos and Rover, 2015; Cruz et al., 2012; Figueiredo and Gazoni, 2016; for an exception, see Lunkes et al., 2015; Matos et al., 2013; Souza et al., 2013; Staroscky et al., 2014). While the information governments publicize as active or open data transparency can be cherry-picked, 'sanitized', or heavily mediated by officials (Michener and Bersch, 2013:239), passive transparency obliges officials to meet the unanticipated information demands of citizens within fixed timeframes. In this sense, passive transparency represents a 'tougher test' of commitments to access public information. In following with other landmark studies on new ATI laws (Camaj, 2016; Hazell and Worthy, 2010; Michener, 2015a; Open Society Justice Initiative, 2006), this study aims to start filling the abovementioned gap by focusing on compliance with passive transparency in Brazil.

This paper is organized as follows. The first part briefly analyzes Brazil's ATI law and then describes paradigmatic incentive structures shaping governmental commitments to ATI in the Brazilian context. Here, we note the most important deficit in Brazil's ATI regime: independent enforcement and oversight to ensure implementation and compliance with the law.

The second part examines ATI performance across Brazil, comparing disclosure within the executive branches of governments at the state, municipal, and federal levels. The data make clear that - five years after taking effect - commitments to Brazil's ATI law are relatively weak and incipient, with a few important exceptions, including a stronger showing by the federal government.

The third part of this paper examines two sets of statistical relationships with respect to demographic and institutional indicators. Somewhat unsurprisingly, we find that jurisdictions with higher human development indicators (HDI) tend to be more compliant with transparency norms. Perhaps more

\footnotetext{
${ }^{1}$ The Public Transparency Program of the FGV is joint collaboration between the Brazilian School of Public and Business Administration (EBAPE) and the Law School - FGV Direito Rio. This report was made possible with funding from the Open Society Foundation.
} 
novel is the finding that making ATI requests through web-based request-and-response platforms (the equivalent to Brazil's e-SIC), as opposed to generic contact forms or emails, is associated with more than double the odds of receiving a response.

\section{THE LAW AND INCENTIVES FOR COMPLIANCE WITH ATI IN BRAZIL}

\subsection{BACKGROUND ON LAW 12.527/2011}

The basis of Brazil's ATI law is comparatively broad and deep, encompassing all levels of government, branches, and all entities responsible for administrating public money, from non-profits that provide government services to state-owned-enterprises. Of the 115 ATI laws around the world, the authoritative Right-to-Information Rating (RTI-Rating) now ranks Brazil's as the $22^{\text {nd }}$ strongest - on paper. $^{2}$ The basis for Brazil's ATI law resides not only in the constitution (especially article 5 [XXXIII]), but in laws enacted throughout the 1990s and 2000s, such as those on Administrative Improbity, the Fiscal Responsibility Law, and the "Clean Slate Law" (Ficha Limpa), among others (Bernardes, Santos and Rover, 2015).

\subsection{INCENTIVES FOR COMPLIANCE — GOOD GOVERNMENT LEGITIMACY, MONITORING, INSURANCE, AND OVERSIGHT}

While an ATI law may be strong on paper, ensuring fulsome implementation and compliance is notoriously difficult. As the literature shows, understanding what incentive structures drive commitments to ATI is critical for designing advocacy, training, and institutional strategies (Berliner, 2014; Hood, 2010; Michener, 2015a; Roberts, 2006; Schnell, 2017). This section thus explores the incentive structures at work in Brazil's ATI regime.

Brazil's large coalition governments make increased transparency a useful mechanism for presidents, governors or mayors pursuing inter-coalitional monitoring and deterring maladministration by coalition partners holding key cabinet portfolios. It is also useful for federal watchdogs to keep track of the recipients of federal funds, including the country's more than 5000-odd municipalities. Yet while monitoring is particularly useful in ideologically heterogeneous coalitions (Pereira et al., 2017:17), pressures to protect allies from public scrutiny will likely outweigh the benefits of monitoring as a coalition's ideological homogeneity increases.

In general, coalition 'partners' tend to resist being monitored in their respective portfolios (Michener, 2015a; Pereira et al., 2017). The final six months of law 12.527's legislative approval process provide a case-in-point. President Dilma Rousseff had agreed to co-chair the Open Government Partnership (OGP) in collaboration with US President Barack Obama and publicly declared her hope to see the Senate approve a half-sanctioned ATI law well in advance of the OGP's inauguration at the

\footnotetext{
${ }^{2}$ See, <www.rti-rating.org/country-data/.Brazil scores $6 / 6>$ for the right to access, 29/30 for the scope of the law, $19 / 30$ for requesting procedures, $16 / 30$ for exceptions, $22 / 30$ for appeals, $3 / 8$ for sanctions and protections, and 13/16 for promotional measures.
} 
United Nations (UN) in September of 2011. Yet in the end, the Senate approved the law only a month after the inauguration, in October 2011. The cause was an embarrassing five-month standoff by Senator Fernando Collor's Defense and Foreign Affairs Committee, which tried to replace the ATI bill with an aberrant substitute. Even a plea from Rousseff's Chief of Staff to the President of the Senate, José Sarney (PMDB), and to Senator Collor (PTB) - both members of Rousseff's coalition - did not spur prompt action. This example illustrates how coalition allies, often aligned with bureaucratic resisters, may eschew transparency. After all, transparency limits discretion, the currency of delegated power.

While leaders of large coalition governments may find ATI laws attractive as monitoring mechanisms, they may also insert them into competitive strategies to neutralize the advantages of partisan opponents or insure the prospective independence of government agencies in case of partisan alternation. Commitments to ATI are especially likely to arise in competitive environments and during partisan alternations of power (Berliner, 2014; Berliner and Erlich, 2015; Michener, 2011). Take the case of the current Governor of Maranhão, Flávio Dino (PCdoB - MA), who not only governs a heterogeneous coalition, but also a state long-dominated by the Sarney family PMDB political dynasty. Upon assuming power in 2015, Dino threw open the doors to the state administration, creating the Transparency and Control Agency (Secretaria de Transparência e Controle - STC), passing regulations to regiment the federal ATI law (decree 10.217/2015), and launching a transparency portal. Maranhão went from a score of 2.2 out of 10 on the first 2015 edition of the CGU's Brazil Transparency Scale (Escala Brasil Transparente) to the maximum score of 10 in 2016 and 2017. The state also went from recording 339 requests in 2015 to 1159 in 2016 - more than a threefold increase in a single year.

More often than not, however, neither symbolic legitimacy, monitoring, nor competitive concerns result in commitments to transparency in Brazil. State and local politicians often place a higher premium on opacity than transparency. Real commitments to transparency, after all, mean that governments have provided enough information to render themselves susceptible to criticism. Providing no information simply signifies non-compliance, which has particularly low costs when the news media and institutional oversight is weak or inexistent. A case-in-point is the state of Rio de Janeiro, which failed to adequately regulate, implement, and comply with the law during a period of unprecedented international exposure (2014 World Cup, 2016 Olympics) (Michener, 2016:6-62; Michener, Moncau and Velasco, 2014:40-44). The Rio case also featured an ideologically homogenous coalition and a lack of partisan alternation, both conditions that theoretically weaken commitments to transparency.

Independent oversight is arguably the most important ingredient in a successful ATI regime (Neuman, 2009; Nino, 2010). Yet research undertaken for this paper shows that of Brazil's 27 states $^{3}$ and 26 state capitals, only 16 and 10 assign oversight responsibility, respectively. ${ }^{4}$ These are de jure

\footnotetext{
${ }^{3}$ In this paper, the Federal District is always included in all descriptions of 'states'.

${ }^{4}$ The regulations from Amapá, Sergipe, Pará, Aracaju, São Luís and Belém could not be found. The following regulations make reference to designated agencies for oversight: the cities include Belo Horizonte, Boa Vista, Brasília, Campo Grande, Curitiba, Fortaleza, Goiânia, João Pessoa, Maceió, Manaus, Natal, Porto Velho, Recife, Rio Branco, São Paulo, Vitória; the states include AC, AL, CE, DF, GO, PB, PE, PI, PR and SP.
} 
statutes for oversight; as the data in the following sections suggest, the de facto practice of oversight may be even rarer.

\section{GAUGING COMPLIANCE AND IMPLEMENTATION BY THE NUMBERS: EVALUATIONS AND OFFICIAL DATA}

\subsection{DATA COLLECTION AND DEFINITIONS}

The following pages present analyses of data collected from two sources. First, official data provided by the public prosecutor, subnational governments - including states, state capitals and - the federal government. We obtained this information through official reports and statistics found online. When the jurisdiction or agency's website did not provide data on received requests and requesters' profiles, the authors sent ATI requests to procure it. Second, we listed all known evaluations of compliance with passive transparency undertaken by academic and advocate researchers in Brazil since 2013, and contacted these authors in order to have access to their databases. With data gathered from nine evaluations, ${ }^{5}$ we created a new database consisting of 3550 ATI requests.

In analyzing the compliance of public institutions with access to information requests, this study focuses on three basic metrics: response rates, accuracy rates (when available), and request-to-response time in days. Response rates are calculated as a percentage of total requests that received responses. A response is defined as any kind of directed communication sent via email or accessible through a platform that is not an automatically generated message or an update message related to the internal processing of a request. Accuracy rates are calculated as the percentage of responses in which the response minimally answers the question being asked. For example, if details on expenditures are requested and the response provides regulations on expenditures, the response is not accurate. If partial or full information on expenditures is provided, the response would be scored as minimally or maximally accurate, respectively.

In line with better practice methods (Lacy et al., 2015), responses and accuracy scores in all official studies published by FGV's Public Transparency Program (FGV-PTP) are double-coded based on strict protocols. Coding disagreements are resolved by awarding the maximum score, as per a "benefit of the doubt" logic.

\subsection{SUMMARY OF OVERALL RESULTS — EVALUATIONS ACROSS BRAZIL}

Table 1 presents all results from our database of 3550 requests, compiled from evaluations across Brazil.

Aggregate results from all three branches of government show that requests made to federal bodies had a higher average response rate $(91 \%)$ than state $(53 \%)$ or municipal bodies $(44 \%)$. The overall response rate for Brazil averaged $62 \%$, but only $52 \%$ of responses - or one out of every three requests - was scored as minimally accurate or better. The average request-to-response time was 18 days, but almost $50 \%$ of requests went beyond the 30 -day maximum. These results clearly illustrate that compliance is weak, and upcoming sections detail the particulars of these results.

\footnotetext{
${ }^{5}$ Article 19 (2014b, 2015, 2016); Borges (2015); Michener (2016); Michener, Moncau and Velasco (2014); Michener and Velasco (2015); Moncau and collaborators (2015); Michener, Rodrigues and Velasco (2018).
} 
RAP | From opacity to transparency? Evaluating access to information in Brazil five years later

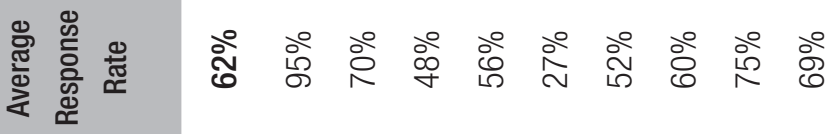

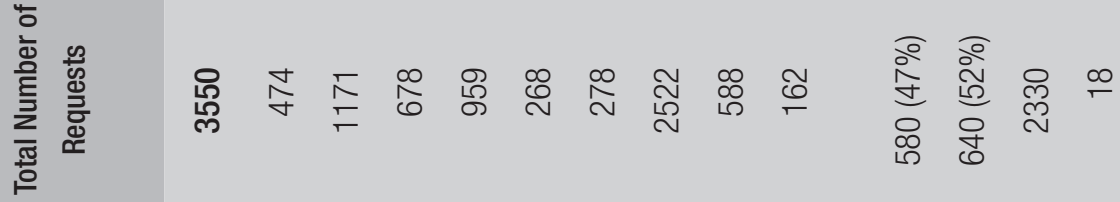

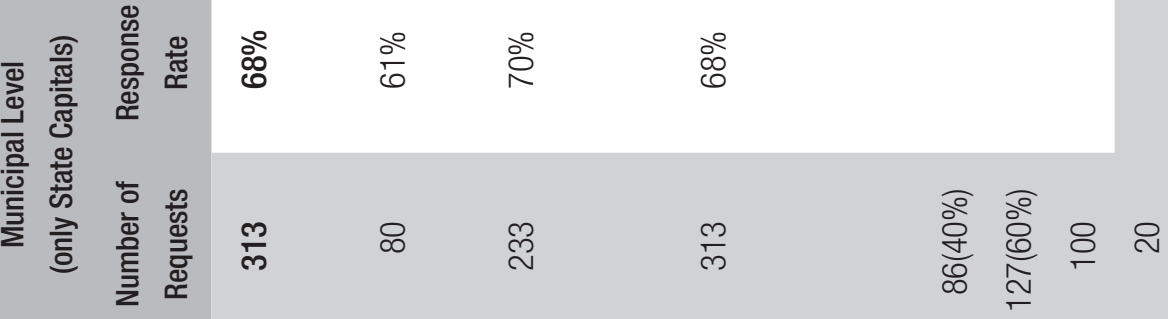

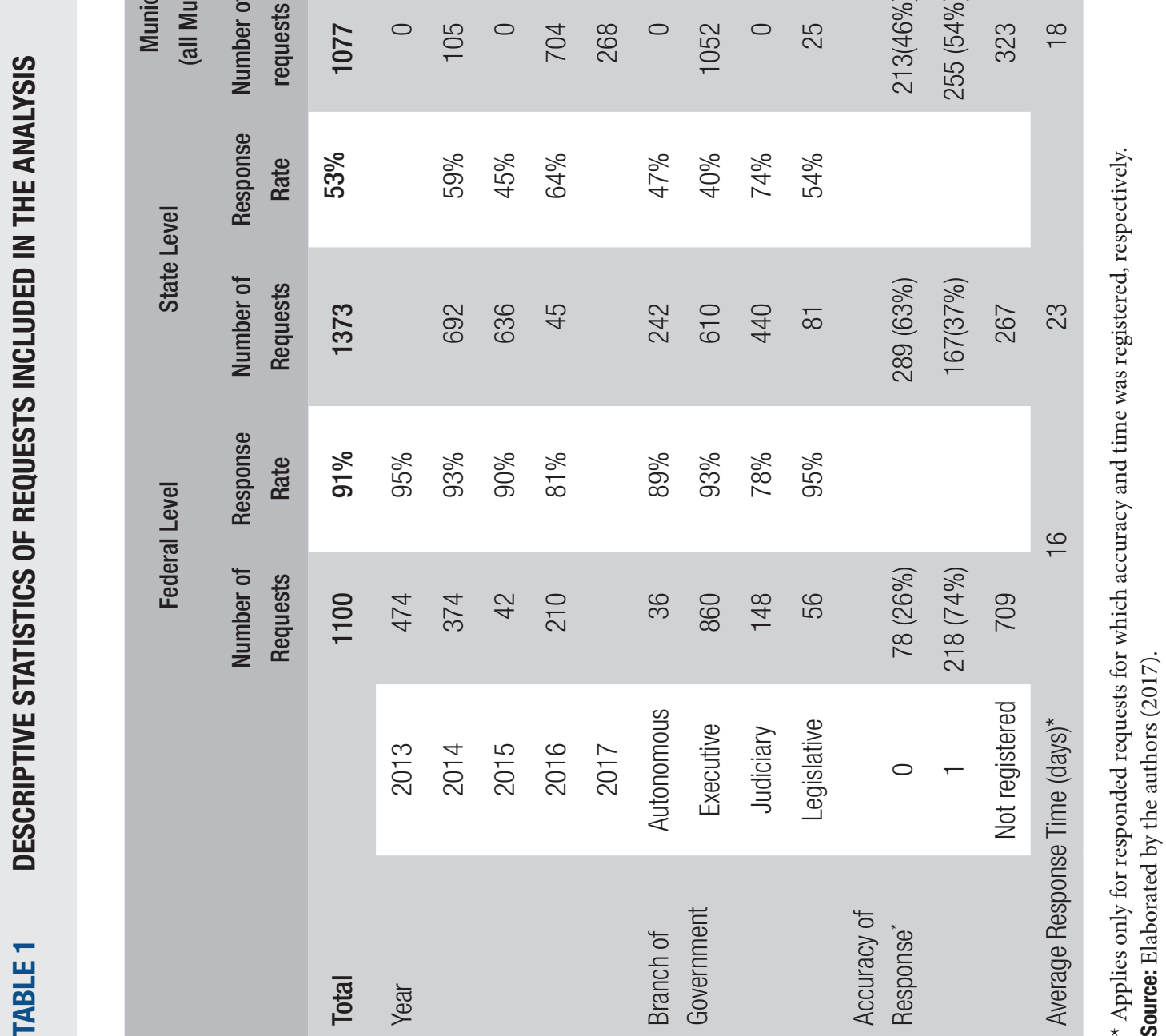

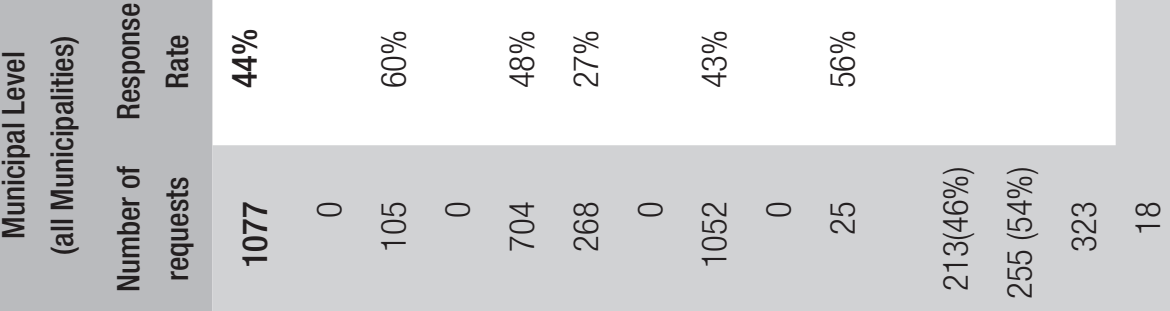




\subsection{MUNICIPAL AND STATE COMPLIANCE WITH ACCESS TO INFORMATION IN BRAZIL}

Most government happens locally, on the streets, schools, hospitals, and leisure spaces of cities. Yet ironically, transparency is weaker at the local level in Brazil, which is the opposite of what researchers tend to find in countries such as the United States or Canada. This constitutes an important paradox, as governments that are closer to citizens should be easier to hold to account (Michener, 2016:15-17).

Table 2 presents results on compliance for the executive branches of subnational governments. The results show large variation, with municipalities responding to less than one in two requests and providing accurate responses to less than one in four requests. State capitals fare slightly better, with two of every three requests garnering a response, and two of every five requests being answered in an accurate manner. State compliance levels are particularly low, with little more than one in every nine requests garnering an accurate response. Overall, the aggregate numbers show that more than one out of every two requests are being ignored at the subnational level.

\section{TABLE 2 COMPLIANCE WITH PASSIVE TRANSPARENCY (REQUESTS) BY SUBNATIONAL GOVERNMENTS}

\begin{tabular}{lccc} 
& Municipalities & State Capitals & States \\
\hline Number of Requests & 1052 & 313 & 610 \\
\hline Response Rate & $43.3 \%$ & $68 \%$ & $40 \%$ \\
\hline Accuracy Rate & $54.2 \%$ & $59.6 \%$ & $31.8 \%$ \\
\hline Average Response Time (in days) & 17.4 & 19.8 & 25.4 \\
\end{tabular}

Source: Elaborated by the authors (2017).

In 2016, the Public Transparency Program (FGV) released a report on state and municipal transparency in Brazil (Michener, 2016). Among the 313 requests sent out, 53 percent received a response, of which 87 percent were deemed minimally accurate or better. Thus when municipalities responded they almost invariably did so accurately. Coincidentally, it was also these responsive municipalities that reported having implemented an ATI unit (Padilha and Michener, 2016). These results illustrate the importance of implementation and oversight.

This conclusion was reinforced by 73 follow-up phone calls made to the 20 municipalities that did not respond to any of the FGV requests. What researchers found was a marked lack of awareness (Michener, 2016:179). For example, in nearly 50 percent of calls, officials asked why researchers wanted the information, which is illegal as per Brazil's ATI law (article $10 \$ 3^{\circ}$ ). Furthermore, officials in 57 percent of jurisdictions did not know what agency was responsible for complaints regarding access to public information, often directing calls to the information technology (IT) department. 
In an interview, the CGU official responsible for federal-subnational cooperation, Álvaro de Souza, ${ }^{6}$ explained that local officials justify poor compliance by pointing to problems of accessing the internet or technical abilities. According to Souza, local governments also claim they do not have the budget to comply with the law (Souza, 2017).

One among many examples, however, make these 'under-resourced' arguments difficult to accept at face value. Take the example of Cacaulândia, a small town of 6268 inhabitants in the Amazonian state of Rondônia. The per annual capita income in 2014 for the municipality was R $\$ 18,460$ (about US\$6000), yet despite its very humble means, the municipality signed the CGU's Program for a Transparent Brazil (Programa Brasil Transparente) in 2013, regulated the law the same year (decree 2005), and in 2015 it became one of only 31 cities to achieve a perfect score of 10 on the CGU's Brazil Transparency Scale (Escala Brasil Transparente). In addition to keeping an updated transparency portal, the three officials who take care of transparency recorded responses to 46 ATI requests between 2014 and 2016, and - to maximize public trust - post meticulous records of power outages on the town's transparency portal, the result of Rondônia's precarious grid. The costs of good performance are surprisingly low. From the start of the regulatory initiative in 2013 to May 2017, officials in Cacaulândia have spent approximately $\mathrm{R} \$ 5000$ (about US\$ 1500) on direct costs associated with the ATI law, according to the municipal comptroller.

As Cacaulândia and the FGV's telephone calls to local governments suggest, non-compliance has less to do with budgets and technical abilities and more to do with incentives and leadership.

\subsubsection{INDICATORS OF IMPLEMENTATION — REQUESTS AND REQUESTERS}

Indicators of implementation clearly show that leadership is lacking in most Brazilian jurisdictions. A first-order marker of oversight and implementation is the presence or absence of statistics on ATI requests and requesters (Camaj, 2016; Hazell and Worthy, 2010; Michener, 2015a). The statistics kept by the CGU concerning the federal executive are some of the most extensive in the world. Table 3 illustrates the most basic of these statistics. While we examine the federal executive in later sections, table 3 serves to provide a benchmark.

TABLE 3 OFFICIAL GOVERNMENT DATA ON FEDERAL EXECUTIVE, 2016 AND (2012-16)

\begin{tabular}{lccccccc}
$\begin{array}{l}\text { Number of } \\
\text { requesters }\end{array}$ & $\begin{array}{c}\text { Number of } \\
\text { Requests }\end{array}$ & \% Responses & $\begin{array}{c}\text { \% Full or } \\
\text { Partial } \\
\text { Responses }\end{array}$ & $\begin{array}{c}\text { \% Partial } \\
\text { Responses }\end{array}$ & \% Denials & $\begin{array}{c}\text { Request-to- } \\
\text { Response } \\
\text { Time in Days }\end{array}$ & $\begin{array}{c}\text { Number of } \\
\text { Appeals }\end{array}$ \\
\hline 57,438 & 111,669 & $99.39 \%$ & $67.55 \%$ & $6.36 \%$ & $10.02 \%$ & $14.61(14)$ & 14,926 \\
$(233,433)$ & $(446,132)$ & $(99.8 \%)$ & $(71.36 \%)$ & $(4.45 \%)$ & $(11.64 \%)$ & $(50,833)$ \\
\hline
\end{tabular}

Source: Elaborated by the authors (2017).

${ }^{6}$ Interview granted do Irene Niskier in March, $8^{\text {th }}$ 2017. Brasília. 


\subsubsection{REQUESTS FOR STATES AND STATE CAPITALS}

Examining responses received by the PTP and websites for Brazil's state capitals, researchers were only able to find 2016 data on the number of requests for 11 of Brazil's 26 capital cities. ${ }^{7}$ Among state capitals, only Belo Horizonte, João Pessoa and Rio de Janeiro had statistics on all years since the law took effect (2012-2016).

The number of requests per state capital varies immensely. In Curitiba, officials received 1307 requests in 2016. By contrast, citizens of Salvador made 113 requests the same year. In other words, Salvador, a city with a third more people than Curitiba, had nearly 10 times fewer requests.

The statistics for Brazil's states are slightly more complete than for state capitals, but are still quite deficient. Of Brazil's 27 states, 18 had information on the number of requests in $2016 .{ }^{8}$ Eleven possess information on the number of requests received since the law took effect (2012-2016). ${ }^{9}$

Citizens and organizations in the DF sent more than 8 times the amount of requests (5846) than did their counterparts in Pernambuco (699), which has about three times DF's population.

Calculating the median requesting rate for states and state capitals, in 2016 we find 1148 requests for states and 445 for state capitals. Even though these numbers admit enormous variation, they are still relatively tiny. That is not to say that the requesting trends of some jurisdictions lack promise. São Paulo's 44.85 million people sent nearly 18,000 requests to the state government in 2016 (0.4 requests per 1000 citizens). This result is approximate to that of Brazil's federal government, which received 111,669 requests in 2016 ( 0.5 requests per 1000 citizens). By comparison, Canada, a country with a population of 35.85 million and whose ATI law has been in force since 1984, recorded 75,387 requests in 2015-2016 (2.1 requests per 1000 citizens). Other Brazilian states show less promising trends than São Paulo, however. Mato Grosso, with a population of 3.3 million, recorded a mere 368 requests ( 0.1 requests per 1000 citizens).

\subsubsection{REQUESTERS}

Information on requesters is rare at the subnational level. Of the 17 jurisdictions (among 27 states and their 26 capitals) that possess statistics on requesters, only 2 states and no municipalities present data on the number of requesters (AM, MG). Amapá and Minas Gerais's statistics on the number of requesters show approximately two times fewer requesters as requests. These numbers are consonant with the international experience, wherein a small number of requesters tend to make up a disproportionately large number of requests (Hazell and Worthy, 2010).

From the extant data, we know that the average requester is a university-educated male. This data-point is line with international observations (see, for example, Calland and Bentley, 2013:S96). Statistics on the profession of requesters are uncommon, with only Tocantins and João Pessoa gathering such data. In Tocantins, the second largest requester group by profession is public servants (28.5\%). This result is similar to the federal government, where public servants from all levels of government

\footnotetext{
${ }^{7}$ Belo Horizonte, Boa Vista, Curitiba, Florianópolis, Goiânia, João Pessoa, Macapá, Maceió, Recife, Rio de Janeiro, and Salvador.

${ }^{8}$ These states are: AL, AM, CE, GO, MA, MG, MS, MT, PA, PB, PE, PR, RN, RS, SC, SE, SP, TO.

9 These include: AL, CE, GO, MG, MT, PA, PB, RS, SE, SP and TO.
} 
make up nearly 22 percent of requesters. High use of ATI laws by public servants accords with extant knowledge on ATI; laws serve as effective means of information acquisition within governments themselves (Michener, 2018).

\subsubsection{PROGRAMA BRASIL TRANSPARENTE, REGULATIONS, AND REQUESTING PLATFORMS}

The CGU has worked to remedy weak implementation in the states and municipalities within the constraints of a small budget and limited constitutional reach. One tactic has been to motivate subnational governments to commit to the Programa Brasil Transparente (PBT or 'Program for a Transparent Brazil'), an informal pledge to regulate and implement the ATI law. As of May 2017, 1186 municipalities had signed the CGU's PBT, with 14 states and six state capitals yet to sign the agreement. ${ }^{10}$ Signing the PBT should not, of course, be taken as a de facto commitment to ATI. Casein-point, the state of Acre signed the PBT, but has yet to regulate the federal law.

Furthermore, the regulations elaborated by some governments omit critical provisions of the federal law (refer to Michener, 2016:35-36). Perhaps the most brazen break with the federal law is the absence of sanctions for public servants that violate the ATI. States that make no mention of sanctions include AC, AL, GO, MS, RN, RR, RS and SC; and state capitals include Campo Grande, Teresina, Rio de Janeiro, and Florianópolis.

As the Third Part of this paper will show, the official online channels through which citizens request information significantly impacts how well governments respond. The electronic access to information platform developed by the federal Comptroller General (known as the e-SIC) permits citizens to launch requests and appeals, as well as viewing responses online. Despite the fact that the CGU freely provides software and technical instruction for the implementation of e-SICs, eight states and 12 state capitals still have no such systems. ${ }^{11}$

Having examined subnational indicators of implementation, including requests, requesters, signed commitments to Programa Brasil Transparente, regulations, and electronic requesting systems (e-SIC), the evidence shows that - five years after ATI law 12.527 took effect - implementation at the subnational level is spotty at best. The numbers on compliance, analyzed earlier, confirm this basic assessment.

\subsection{THE FEDERAL GOVERNMENT AND THREE CHALLENGES FOR FULLER AND FAIRER ACCESS}

As official government statistics suggest (refer to table 3), the federal government is operating at a higher level than all other institutions in Brazil. While the federal government's statistics on response rates - 99.39\% - are difficult to accept at face value, multiple academic and advocacy-based evaluations have indeed found high levels of compliance (refer to table 1). Nearly $80 \%$ of responses were deemed to be minimally accurate or better. Relative success at the federal level has a clear rationale: strong oversight by the Comptroller General (CGU). ${ }^{12}$

\footnotetext{
${ }^{10}$ State capitals that have not yet signed the PBT include: Aracaju, Belém, Cuiabá, Rio de Janeiro, Salvador, and Teresina; and states include: AL, BA, CE, GO, MA, MT, PA, PB, PE, PR, RJ, RR, SC, SP.

${ }^{11}$ States that have implemented no e-SIC-type systems include AL, AP, CE, ES, PR, RJ, RN, SE; and state capitals include Belo Horizonte, Cuiabá, Curitiba, Fortaleza, João Pessoa, Manaus, Natal, Porto Velho, Rio Branco, Rio de Janeiro, Salvador, and Vitória.

${ }^{12}$ Currently renamed as Ministry of Transparency and Comptroller General (CGU).
} 
Yet problems in federal handling of the ATI law persist. First, the quality and completeness of responses cannot be gleaned from statistics presented herein. The FGV is one of few organizations that judges some element of the 'quality' of requests. While FGV uses accuracy metrics and the federal executive presents information on responses that provide 'full' versus 'partial' information ${ }^{13}$ it is difficult to judge quality. By the government's measures, does a response such as, 'the information you have requested does not exist' constitute a full response or a partial response? Certainly, claims of inexistence are problematic around the world (see for example, Alianza Regional Por La Libre Expresión E Información, 2014:27, 85, 101, 130). Greater qualitative analysis is needed to shed light on the question of response quality.

A second set of challenges relates to omissions or loopholes in the law. What are the criteria for classifying documents or for producing or not producing documents? Public interest and harm tests should be adopted to better orient officials on what to classify. After all, the law provides that secrecy be the exception, and openness the rule. In addition to classification problems, article 13 (III) of the federal regulation, decree 7724, provides for several gaping loopholes, wherein officials may deem requests "disproportionate", "unreasonable", or inform requesters that requests are unanswerable because they require "additional work in analysis, interpretation, or consolidation [...] or services of production and data mediation [...] that is not the competence of the institution". These exceptions are abused all too frequently, and lengthy appeals are required to justify and satisfy legitimate requests for public information (Artigo 19, 2014a:26-27).

Finally, a third set of challenges relate to the legal obligation that requesters identify themselves in order to obtain information. Along with advocacy organizations Artigo 19 and Transparency International Brasil, the PTP-FGV has submitted a briefing paper to the CGU urging that requesters' identities be protected during the requesting process, as discussed earlier. The solution is to provide "identity neutrality" provisions (Paterson and Mcdonagh, 2010): to have requesters furnish personal information exclusively to an oversight agency such as the CGU, which would then send out the request to the designated agency without any identifying information in order to protect the requester. The CGU responded to this demand by including a provision in law 13.460 (article $10 \$ 7 \mathrm{o}$ ) that will ostensibly provide some type of 'opt-out' feature for requesters. It remains to be seen whether the new mechanism will resolve dilemmas related to identity.

The challenges of response quality, non-disclosure loopholes, and the negative effects of requester self-identification represent only a few of many challenges faced by the ATI law in Brazil.

\section{TEASING OUT ASSOCIATIONS FROM THE DATA: GOVERNMENT RESPONSIVENESS, REQUESTING PLATFORMS AND LEVELS OF DEVELOPMENT}

In order to better understand the relationship between government responses to ATI requests and institutional and demographic variables, we put together a dataset consisting of 3282 FOI requests from 9 independent evaluations of passive transparency undertaken between 2013 and the end of 2016 (Artigo 19, 2014b, 2015, 2016; Borges, 2015; Michener, 2016; Michener, Moncau and

\footnotetext{
${ }^{13}$ See $<$ https://esic.cgu.gov.br/sistema/Relatorios/Anual/RelatorioAnualPedidos.aspx> .
} 
Velasco, 2014; Michener and Velasco, 2015; Moncau et al., 2015; Michener, Rodrigues and Velasco, 2018). We re-coded all the evaluations to create a dummy variable for response accuracy, where 1 is assigned when a response was "minimally accurate" or better. ${ }^{14}$ Demographic data is from the Human Development Index (HDI), recorded by the Brazilian Institute for Geography and Statistics (IBGE). Table 4 illustrates descriptive statistics for both HDI by quintile and the means of sending requests.

An ATI specific platform, such as the CGU's e-SIC system, is specifically designed to handle ATI requests, whereas a designated channel, such as an ombudsmen's contact form, may include other types of citizen feedback (e.g. complaints) in addition to ATI requests. In table 4, designated and non-designated channels are pooled.

TABLE 4 RESPONSIVENESS BY MEANS OF REQUEST AND QUINTILE OF HDI AT THE MUNICIPAL LEVEL

\begin{tabular}{|c|c|c|c|}
\hline \multirow{2}{*}{ Quintile of HDI } & \multirow{2}{*}{ Number of requests } & \multicolumn{2}{|c|}{ Response rates } \\
\hline & & ATI specific platform & Other means of request \\
\hline 1 & 162 & $35.5 \%$ & $7.2 \%$ \\
\hline 2 & 149 & $44.9 \%$ & $11.7 \%$ \\
\hline 3 & 148 & $45.7 \%$ & $17.9 \%$ \\
\hline 4 & 144 & $55.2 \%$ & $26.3 \%$ \\
\hline 5 & 151 & $71.3 \%$ & $50.7 \%$ \\
\hline
\end{tabular}

Source: Elaborated by the authors (2017).

The descriptive statistics suggest superior response rates via ATI-specific platforms. In order to better understand this association, we carried out a statistical analysis using pooled Poisson and Logistic regressions, controlling for fixed effects due to the different timing and diverse authors represented, and using robust standard errors. This empirical strategy was chosen due to the large number of non-contiguous data in the panel, and its non-random nature, which gave rise to problems of endogeneity.

\subsection{ANALYSIS OF RESPONSIVENESS}

First, we explore which variables are associated with responsiveness. Results for the logistic regressions are shown in table 5, illustrating odds ratios.

The results suggest that for requests sent through a designated ATI channel, the odds of response are $115 \%$ higher $(\mathrm{SE}=0.43, \mathrm{p}<0.01$ ) compared to a non-designated channel, and for those sent through an ATI-specific platform, they are $258 \%$ higher $(\mathrm{SE}=0.48, \mathrm{p}<0.01)$. These effects appear to be even stronger at the municipal level, where, compared to non-designated channels, sending a request

\footnotetext{
${ }^{14}$ The threshold of 0.75 was used to qualify a response as accurate.
} 
through a designated channel is associated with an increase of $290 \%$ (SE $=1.90, \mathrm{p}<0.01$ ) in the odds of a response and $380 \%(\mathrm{SE}=1.04, \mathrm{p}<0.01)$ when it is sent through an ATI-specific platform. At the state level, the use of an ATI-specific platform is associated with an increase of $133 \%$ ( $S E=0.48, \mathrm{p}<0.01)$ in the odds of response. Here, however, whether the system is designated or non-designated seems to make no significant difference.

As expected, we also found a significant and positive relationship between levels of development at the subnational level (models 4 and 5) and responsiveness. One additional point on the HDI ${ }^{15}$ is associated with $0.4 \%$ greater odds of a response to a request at the state level and $0.7 \%$ at the municipal level. Therefore, an increase of 100 points - the approximate difference between many parts of the state of Pará and Rio Grande do Sul — would be associated with 49\% and 101\% higher odds of receiving a response. Even when controlling for HDI at the subnational level, the associations with means of requests remain significant, especially for ATI specific systems.

\section{TABLE $5 \quad$ ANALYSIS OF RESPONSIVENESS}

\begin{tabular}{|c|c|c|c|c|c|}
\hline & (1) & (2) & (3) & (4) & (5) \\
\hline VARIABLES & & & $\begin{array}{c}\text { Federal } \\
\text { Level }\end{array}$ & $\begin{array}{l}\text { State } \\
\text { Level }\end{array}$ & Municipal Level \\
\hline \multirow[t]{2}{*}{ Designated Channel } & & $2.15^{\star \star \star}$ & 1.27 & 1.40 & $3.90^{\star \star \star}$ \\
\hline & & $(0.43)$ & (1.95) & $(0.36)$ & (1.90) \\
\hline \multirow[t]{2}{*}{ ATI-Specific System } & & $3.58^{\star \star \star}$ & 2.32 & $2.33^{\star \star \star}$ & $4.80^{\star \star \star}$ \\
\hline & & $(0.48)$ & (3.25) & $(0.48)$ & $(1.04)$ \\
\hline \multirow[t]{2}{*}{ Branch_Executive } & $2.36^{\star \star \star}$ & $2.37^{\star \star \star}$ & 0.71 & $1.85^{\star \star}$ & $2.40^{*}$ \\
\hline & $(0.48)$ & $(0.50)$ & $(0.69)$ & $(0.45)$ & (1.15) \\
\hline \multirow[t]{2}{*}{ Branch_Judiciary } & 1.30 & $2.02^{\star \star \star}$ & 0.34 & $2.34^{\star \star \star}$ & \\
\hline & $(0.22)$ & $(0.39)$ & $(0.31)$ & $(0.47)$ & \\
\hline \multirow[t]{2}{*}{ Branch_Legislative } & $2.07^{\star \star \star}$ & $1.95^{\star \star \star}$ & 1.10 & $1.72^{\star}$ & \\
\hline & $(0.49)$ & $(0.49)$ & $(1.09)$ & $(0.52)$ & \\
\hline
\end{tabular}

\footnotetext{
${ }^{15}$ Refers to one-thousandth in the original HDI scale.
} 


\begin{tabular}{|c|c|c|c|c|c|}
\hline & (1) & (2) & (3) & (4) & (5) \\
\hline \multirow[t]{2}{*}{ VARIABLES } & & & Federal & State & \\
\hline & & & Level & Level & Municipal Level \\
\hline \multirow[t]{2}{*}{ Level_State } & $0.28^{\star \star *}$ & $0.25^{\star \star \star}$ & & & \\
\hline & $(0.05)$ & $(0.05)$ & & & \\
\hline \multirow[t]{2}{*}{ Level_Municipal } & $0.17^{\star \star \star}$ & $0.24^{\star \star \star}$ & & & \\
\hline & $(0.03)$ & $(0.04)$ & & & \\
\hline \multirow[t]{2}{*}{ HDI (*1000) } & & & & $1.004^{\star \star \star}$ & $1.007^{\star \star \star}$ \\
\hline & & & & $(0.001)$ & $(0.001)$ \\
\hline \multirow[t]{2}{*}{ Constant } & $0.23^{\star \star}$ & 1.39 & 3.87 & $0.02^{\star \star \star}$ & $0.00^{\star \star \star}$ \\
\hline & (0.15) & $(0.46)$ & (6.20) & $(0.02)$ & $(0.00)$ \\
\hline Year fixed effects & Yes & Yes & Yes & Yes & Yes \\
\hline Author fixed effects & Yes & Yes & Yes & Yes & Yes \\
\hline Observations & 3,550 & 2,099 & 328 & 979 & 754 \\
\hline
\end{tabular}

Source: Elaborated by the authors (2017).

Odds Ratios reported. Robust SE in parentheses

${ }^{* * *} \mathrm{p}<0.01,{ }^{* *} \mathrm{p}<0.05,{ }^{*} \mathrm{p}<0.1$

\subsection{ANALYSIS OF THE ACCURACY OF RESPONSES}

Another important outcome variable is the accuracy of responses. Here, we include only those requests that received a response and for which accuracy was evaluated. The results of the logistic regressions are displayed in table 6, below.

\section{TABLE 6 ANALYSIS OF THE ACCURACY OF RESPONSES}

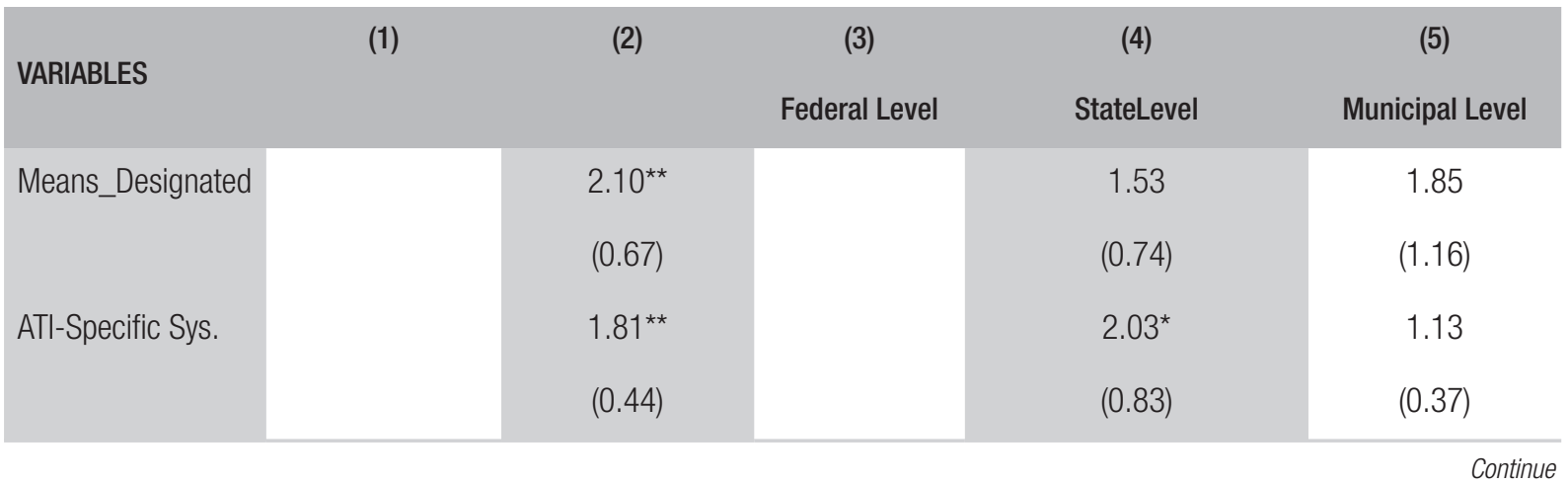


RAP | From opacity to transparency? Evaluating access to information in Brazil five years later

\begin{tabular}{|c|c|c|c|c|c|}
\hline VARIABLES & (1) & (2) & $\begin{array}{c}\text { (3) } \\
\text { Federal Level }\end{array}$ & $\begin{array}{c}\text { (4) } \\
\text { StateLevel }\end{array}$ & $\begin{array}{c}\text { (5) } \\
\text { Municipal Level }\end{array}$ \\
\hline \multirow[t]{2}{*}{ Branch_Executive } & $0.47^{*}$ & $0.49^{\star}$ & 0.58 & 0.48 & 0.39 \\
\hline & $(0.19)$ & $(0.20)$ & $(0.74)$ & $(0.22)$ & $(0.26)$ \\
\hline \multirow[t]{2}{*}{ Branch_Judiciary } & $0.43^{\star \star}$ & $0.48^{\star}$ & 0.87 & 0.78 & \\
\hline & $(0.17)$ & $(0.20)$ & (1.15) & $(0.35)$ & \\
\hline \multirow[t]{2}{*}{ Branch_Legislative } & 0.63 & 0.69 & 0.81 & 0.75 & \\
\hline & $(0.28)$ & $(0.31)$ & $(1.06)$ & $(0.37)$ & \\
\hline \multirow[t]{2}{*}{ Level_State } & $0.31^{\star \star \star}$ & $0.35^{\star \star \star}$ & & & \\
\hline & $(0.06)$ & $(0.07)$ & & & \\
\hline \multirow[t]{2}{*}{ Level_Municipal } & $0.30^{\star \star \star}$ & $0.30^{\star \star \star}$ & & & \\
\hline & $(0.06)$ & $(0.06)$ & & & \\
\hline \multirow[t]{2}{*}{ HDI $\left({ }^{\star} 1000\right)$} & & & & $1.01^{* *}$ & 1.00 \\
\hline & & & & $(0.00)$ & $(0.00)$ \\
\hline \multirow[t]{2}{*}{ Constant } & $4.12^{\star \star \star}$ & 2.02 & 2.00 & $0.01^{* \star}$ & 2.07 \\
\hline & (1.65) & $(1.00)$ & (2.45) & $(0.02)$ & (5.05) \\
\hline Year fixed effects & Yes & Yes & Yes & Yes & Yes \\
\hline Author fixed effects & Yes & Yes & Yes & Yes & Yes \\
\hline Observations & 1,220 & 1,011 & 286 & 425 & 290 \\
\hline
\end{tabular}

Source: Elaborated by the authors (2017).

Odds Ratios reported. Robust SE in parentheses

${ }^{* *} \mathrm{p}<0.01,{ }^{* *} \mathrm{p}<0.05,{ }^{*} \mathrm{p}<0.1$

With respect to the different levels of government, results show that the odds of receiving an accurate response from institutions at the state or municipal level is $65 \%(\mathrm{SE}=0.07, \mathrm{p}<0.01)$ and $70 \%$ $(\mathrm{SE}=0.06, \mathrm{p}<0.01)$ lower, respectively, as compared to the federal level.

Regarding the channel through which requests are sent, the results suggest that designated means have $110 \%(\mathrm{SE}=0.67, \mathrm{p}<0.05)$ higher odds of receiving an accurate response when compared to nondesignated means. Meanwhile, when using an ATI-specific system, the odds of receiving an accurate response are, on average, $81 \%(\mathrm{SE}=0.44, \mathrm{p}<0.05)$ higher. 
We also controlled for levels of development at the subnational levels (models 4 and 5). The results suggest that an additional one point on the HDI is associated with a $1 \%(\mathrm{SE}=0.002, \mathrm{p}<0.05)$ increase in the odds ratio of accuracy at the state level. A similarly significant relationship did not occur at the municipal level.

In sum, higher levels of HDI improve responsiveness and accuracy, as do ATI specific platforms, with each variable exhibiting independent effects.

\section{CONCLUSION AND RECOMMENDATIONS}

Examining government statistics and 3550 requests submitted by evaluators across Brazil, this paper has assessed how well governments across Brazil are implementing and complying with Brazil's five-yearold ATI law (12.527). In line with other studies conducted on subnational transparency since 2013 (see, for example, Figueiredo and Gazoni, 2016; Lunkes et al., 2015; Souza et al., 2013) our evidence shows that both compliance and implementation are patchy and generally weak. This article, however, aimed to start filling the gap left by previous research, which mainly concentrated on active transparency. By combining data and results from the universe of known passive transparency evaluations and creating a new database of requests, we contribute to scholarship on public administration and transparency by shining light on how Brazilian governments are complying with core transparency obligations. In future research, the goal is to move into greater depths, exploring cases studies such as the puzzling case of Rio de Janeiro - a state that is comparatively rich but highly opaque. Several other variables deserve greater scrutiny in determining levels of access. Most prominently, the size, legislative weight, and formation of coalitions should impact propensities to lead on the question of transparency.

Perhaps the more important priority is to move towards policy prescription. What can be done to bolster a law that is not only important for accountability and participation, but that also obligates governments to provide and organize the information required to coordinate Brazil's complex three-tiered federalism? If drastic action is not taken, the outlook for ATI compliance and implementation across Brazil will remain dire. The great lacuna in Brazil is subnational oversight in the form of institutions devoted to regulating and enforcing information management and disclosure practices. Indeed, the general weakness of accountability and transparency institutions at the subnational level is one of the country's Achilles' heels. Given the importance of information in the Twenty-First Century, it is no wonder that more and more countries continue to adopt information commissions, including Mexico, Chile, the UK, India, and Canada, among close to 30 others. In Brazil's states and cities, efforts should be made to appoint one specific authority (e.g. an information commissioner or a comptroller) as guardian of the ATI law. Right now, ATI has no consistency, with the auditing courts (tribunais de contas), comptrollers, and public prosecutors all assuming responsibilities in different parts of the federation.

The current study was limited to examining the executive branch, but the performance of other institutions, including Brazil's judiciary and the public prosecutor (Ministério Público), make clear that retarded commitments to ATI are pervasive (Michener, Moncau and Velasco, 2014; Moncau and collaborators, 2015). Only 1 of $27^{16}$ state courts and seven of 27 public prosecutor offices provide

\footnotetext{
${ }^{16}$ The Federal District is counted as a state for the purposes of analysis.
} 
statistics on requests (refer to table 1). Moreover, state courts respond accurately to only one in four requests. In the case of the state public prosecutors, only one in three requests obtains an accurate response. For institutions that are supposed to uphold the law and defend fundamental rights, this is lamentable performance. Resolutions by the oversight bodies of the judiciary and public prosecutor are very general and, in the case of remuneration, continue to be largely ignored (Venturini, 2017).

This paper focused exclusively on passive transparency but it is clear that active transparency performance has its own set of challenges. Different institutions and jurisdictions use websites with different structures, terminologies, and formats that vex and confuse citizens and preclude a standardized use of robots to evaluate transparency. Similarly, information on remuneration and benefits, especially in the judiciary, are often provided in closed formats and explained in language so truncated or arcane as to be unintelligible - even for legal scholars. All of these challenges suggest the need for standardization and simplification - greater information governance in the form of a strong central authority.

Given the challenges of ATI in Brazil, this review paper concludes with five recommendations:

1. That all jurisdictions assign oversight responsibilities to a central agency, preferably an information commission. Ideally, Brazil would adopt a supranational institution such as Mexico's National Institute for Information (INAI). The lack of independent oversight is Brazil's most important deficit in terms of improved information governance.

2. That all levels of government and all branches implement ATI units within each agency to oversee compliance, implementation, regulation, and promotion of the law.

3. That all agencies and jurisdictions adopt ATI-specific online platforms by which citizens can request information, accompany responses, and launch appeals. As the third part of this paper shows, such platforms are significantly associated with higher compliance.

4. That all jurisdictions adopt identity-neutral means of requesting information or protection for requesters. Studies show that officials are actively Googling requesters, which is affecting the quality and likelihood of responses and is likely deterring use of the ATI law.

5. That reforms be passed to a) fill gaps in the regulations of many subnational governments, such as the absence of sanctions; b) clarify or amend the exceptions relating to article 13 of federal decree 7724; and, c) provide for harm and public interest tests to better justify information reserved as classified. 


\section{REFERENCES}

ALIANZA REGIONAL POR LA LIBRE EXPRESIÓN E INFORMACIÓN. Saber más VI: informe regional sobre acceso a información pública y apelaciones. Montevidéu: Fundar, 2014.

AMORIM NETO, Octavio. Presidential cabinets, electoral cycles, and coalition discipline in Brazil. Dados, v. 43, n. 3, p. 479-519, 2000.

ARTIGO 19. Caminhos da transparência: a Lei de Acesso à Informação e os Tribunais de Justiça. São Paulo: Artigo 19, 2016.

ARTIGO 19. El acceso a la información y sus instancias de control y apelación en Brasil. In: ALIANZA REGIONAL POR LA LIBRE EXPRESIÓN E INFORMACIÓN. Saber más VI: informe regional sobre acceso a información pública y apelaciones. Montevidéu: Fundar, 2014a.

ARTigO 19. Monitoramento da Lei de Acesso à Informação Pública em 2013. São Paulo: Artigo 19, $2014 b$.

ARTIGO 19. Monitoramento da Lei de Acesso à Informação Pública 2014. São Paulo: Artigo 19, 2015.

BAIRRAL, Maria Amália C.; SILVA, Adolfo H. C.; ALVES, Francisco José S. Transparência no setor público: uma análise dos relatórios de gestão anuais de entidades públicas federais no ano de 2010. Rev. Adm. Pública, Rio de Janeiro, v. 49, n. 3, p. 643-675, May/June 2015.

BERLINER, Daniel. The political origins of transparency. Journal of Politics, v. 76, n. 2, p. 479-491, Apr. 2014.

BERLINER, Daniel; ERLICH, Aaron. Competing for transparency: political competition and institutional reform in Mexican states. American Political Science Review, v. 109, n. 1, p. 110-128, Feb. 2015.

BERNARDES, Marciele; SANTOS, Paloma; ROVER, Aires. Ranking das prefeituras da região Sul do Brasil: uma avaliação a partir de critérios estabelecidos na Lei de Acesso à Informação. Rev. Adm. Pública, Rio de Janeiro, v. 49, n. 3, p. 761-792, May/June 2015.

BORGES, Eduardo B. P. Transparência da Governança Florestal na Amazônia: uma análise de cumprimento da Lei de Acesso à Informação nos estados. 2015. 78 f. Thesis (Professional Master Degree in
Public Administration) - Escola Brasileira de Administração Pública e de Empresas, Fundação Getulio Vargas, Rio de Janeiro, 2015.

CALLAND, Richard; BENTLEY, Kristina. The impact and effectiveness of transparency and accountability initiatives: freedom of information. Development Policy Review, v. 31, p. s69-s87, 2013.

CAMAJ, Lindita. From "window dressing" to "door openers"? Freedom of information legislation, public demand, and state compliance in South East Europe. Government Information Quarterly, v. 33, n. 2, p. 346-357, Apr. 2016.

CRUZ, Cláudia et al. Transparência da gestão pública municipal: um estudo a partir dos portais eletrônicos dos maiores municípios brasileiros. Rev. Adm. Pública, Rio de Janeiro, v. 46, n. 1, p. 153-176, Jan./Feb. 2012.

DARCH, Colin; UNDERWOOD, Peter G. Freedom of information and the developing world. Oxford: Chandos Publishing, 2010.

FIGUEIREDO, Vanuza; GAZONI, Rosenclever. Transparência nos sites do estado do Rio de Janeiro. Revista Contabilidade e Controladoria, v. 8, n. 1, p. 130-143, May/Aug. 2016.

HAZELL, Robert; WORTHY, Ben. Assessing the performance of freedom of information. Government Information Quarterly, v. 27, n. 4, p. 352-359, 2010.

HOOD, Christopher. The blame game: spin, bureaucracy, and self-preservation in government. Princeton: Princeton University Press, 2010.

LACY, Stephen, et al. Issues and best practices in content analysis. Journalism \& Mass Communication Quarterly, v. 92, n. 4, p. 791-811, 2015.

LUNKES, Rogério et al. Transparência no setor público municipal: uma análise dos portais eletrônicos das capitais brasileiras com base em um instrumento de apoio à decisão. Revista da Controladoria-Geral da União, v. 7, n. 10, p. 88-108, July 2015.

MATOS, Nyalle et al. Avaliação de portais de transparência dos 30 municípios mais populosos da Região Nordeste. ReCont - Registro Contábil, v. 4, n. 2, p. 17-35, 2013.

MICHENER, Gregory. Assessing freedom of information in Latin America a decade later: 
illuminating a transparency causal mechanism. Latin American Politics and Society, v. 57, n. 3, p. 77-99, Sept. 2015a.

MICHENER, Gregory. FOI laws around the world. Journal of Democracy, v. 22, n. 2, p. 145-159, 2011.

MICHENER, Gregory. How Cabinet Size and Legislative Control Shape the Strength of Transparency Laws. Governance, v. 28, n. 1, p. 77-94, 1 Jan. 2015b.

MICHENER, Gregory (Ed.). Local transparency in Brazil: evaluating compliance with the access to information law in the states and largest cities. Rio de Janeiro: FGV; Open Society Foundations, 2016.

MICHENER, Gregory. Surrendering secrecy: freedom of information in Latin America. Cambridge: Cambridge University Press, 2018. Forthcoming.

MICHENER, Gregory; BERSCH, Katherine. Identifying transparency. Information Polity, v. 18, n. 3, p. 233-242, Jan. 2013.

MICHENER, Gregory; COLIVER, Sandra. The policing of public gatherings - evaluating transparency and access to information. Rio de Janeiro: FGV-Open Society Foundations, 2015.

MICHENER, Gregory; MONCAU, Luiz Fernando; VELASCO, Rafael. The Brazilian State and transparency: evaluating the application of the access to information law. Rio de Janeiro: Fundação Getulio Vargas; Open Society Foundations, 2014.

MICHENER, Gregory; RODRIGUES, Karina F.; VELASCO, Rafael. Googling the Requester: How Disclosure Laws that Mandate Self-Identification Promote Discrimination, 2018. Forthcoming.

MONCAU, Luiz Fernando. et al. Avaliação de transparência do Ministério Público. Rio de Janeiro, Brasil: Fundação Getulio Vargas, 2015.

NEUMAN, Laura. Enforcement models: content and context. Access to Information Working Paper Series. Washington, DC: World Bank Institute, 2009.

NINO, Ezequiel. Access to public information and citizen participation in Supreme Audit Institutions (SAI). Access to Information Working Paper Series. Washington, DC: World Bank Institute, 2010.
OPEN SOCIETY JUSTICE INITIATIVE. Transparency \& silence: a survey of access to information laws and practices in fourteen countries. New York: Open Society Institute, 2006.

PADILHA, Homero; MICHENER, Gregory; CONTRERAS, Evelyn. Avaliando a aplicação da Lei de Acesso nos estados e nas grandes cidades. In: MICHENER, Gregory (Ed.). Transparência local no Brasil: avaliando a aplicação da Lei de Acesso nos estados e nas grandes cidades. Rio de Janeiro: FGVOpen Society Foundations, 2016.

PATERSON, Moira; MCDONAGH, Maeve. Freedom of information: taking account of the circumstances of individual applicants. Public Law: The Constitutional and Administrative Law of the Commonwealth, Research Paper n. 2010/060, p. 505-525, 2010.

PEREIRA, Carlos et al. Watchdogs in our midst: how presidents monitor coalitions in Brazil's multiparty presidential regime. Latin American Politics and Society, v. 59, n. 3, p. 27-47, Sept. 2017.

ROBERTS, Alasdair. Blacked out: government secrecy in the information age. Nova York: Cambridge University Press, 2006.

SCHNELL, Sabina. Cheap talk or incredible commitment? (Mis)calculating transparency and anti-corruption. Governance, p. 1-16, 2017.

SOUZA, Álvaro. Entrevista concedida a Irene Niskier, Brasília, 8 Mar. 2017.

SOUZA, Fábia et al. Índice de Transparência Municipal: um estudo nos municípios mais populosos do Rio Grande do Norte. Revista de Gestão, Finanças e Contabilidade, v. 3, n. 3, p. 94-113, Sept./Dec. 2013.

STAROSCKY, Enéias et al. A transparência dos portais municipais sob a perspectiva da legislação brasileira: o caso de prefeituras em Santa Catarina. Revista Reuna, v. 19, n. 1, p. 29-52, Mar. 2014.

VELASCO, Rafael. "Who wants to know?": a field experiment to assess discrimination in freedom of information regimes. 2016. $50 \mathrm{f}$. Thesis (Master Degree in Administration)jan - Escola Brasileira de Administração Pública e de Empresas, Fundação Getulio Vargas, Rio de Janeiro, 2016. 
VENTURINI, Lilian. Se transparência é regra, por que é preciso mandar divulgar salários de juízes? Nexo Jornal, São Paulo, 3 Sept. 2017. Available at: <www.nexojornal.com.br/expresso/2017/09/03/
Se-transpar\%C3\%AAncia-\%C3\%A9-regrapor-que-\%C3\%A9-preciso-mandar-divulgarsal\%C3\%A1 rios-de-ju\%C3\%ADzes>. Accessed on: 7 June 2018.

\section{Gregory Michener}

Assistant Professor at Fundação Getulio Vargas / Escola Brasileira de Administração Pública e de Empresas (FGV EBAPE), Rio de Janeiro / RJ — Brazil. E-mail: gregory.michener@fgv.br.

\section{Evelyn Contreras}

Fundação Getulio Vargas / Escola Brasileira de Administração Pública e de Empresas (FGV EBAPE), Rio de Janeiro / RJ — Brazil. E-mail: contrerasmedrano@gmail.com.

\section{Irene Niskier}

Fundação Getulio Vargas / Escola Brasileira de Administração Pública e de Empresas (FGV EBAPE), Rio de Janeiro / RJ — Brazil. E-mail: irenenc3@hotmail.com. 